\title{
Originals
}

\section{Infusion of insulin impairs human adipocyte glucose metabolism in vitro without decreasing adipocyte insulin receptor binding}

\author{
L. Mandarino, B. Baker, R. Rizza, J. Genest, and J.Gerich \\ Endocrine Research Unit, Departments of Medicine and Physiology, Mayo Medical School, Rochester, Minnesota, USA
}

\begin{abstract}
Summary. To determine whether hyperinsulinaemia can cause insulin resistance in man and, if so, whether this occurs at a receptor or post-receptor site, nine normal volunteers were infused with insulin for $6 \mathrm{~h}$ at a rate $\left(2 \mathrm{mU} \cdot \mathrm{kg}^{-1} \cdot \mathrm{min}^{-1}\right)$ which resulted in steady-state plasma insulin concentrations of $140 \pm 13 \mathrm{mU} / 1$ and four subjects were infused with saline $(0.45 \%)$. Isolated adipocytes and monocytes were used as models for studying insulin binding, while adipocytes were also used to study insulin action in vitro. Adipocyte insulin binding did not decrease following infusion of insulin $(4.6 \pm$ 0.5 versus $4.4 \pm 0.4 \%$ per $2 \times 10^{5}$ cells, before and after, respectively), whereas monocyte insulin binding did ( $7.2 \pm 0.6$ versus $6.2 \pm 0.6 \%$ per $10^{7}$ cells, $p<0.05$ ). Initial rates of adipocyte 3-0-methyl glucose transport were decreased in the absence of insulin (basal) and at submaximally effective $(33.3 \mathrm{pmol} / \mathrm{l})$
\end{abstract}

but not at maximally effective insulin concentrations. At all insulin concentrations and in the absence of insulin, rates of glucose conversion to lipids were decreased more than $50 \%$ $(p<0.05)$, whereas rates of glucose oxidation were unaffected. This decrease in the rates of conversion of glucose to lipids could not be accounted for by the decrease in rates of glucose transport. These results suggest that hyperinsulinaemia can cause insulin resistance in man and that, at least initially, this occurs at a post-receptor site. Furthermore, the discordant effect of hyperinsulinaemia on monocyte and adipocyte insulin binding indicates that monocyte insulin binding may not always reflect insulin binding in insulin-sensitive tissues.

Key words: Hyperinsulinaemia, insulin resistance, adipocytes, receptors.
Insulin resistant states, such as obesity and Type 2 (noninsulin-dependent) diabetes mellitus, are often associated with hyperinsulinaemia, decreased insulin receptor binding, and post-receptor defects in insulin action [1]. It has been suggested that hyperinsulinaemia seen in human obesity may produce insulin resistance secondarily at a post-receptor site [1-4] as a consequence of prolonged compensatory hyperinsulinaemia due to an initial decrease in insulin receptor binding. Moreover, the post-receptor defect in insulin action, as well as the insulin receptor down-regulation found in Type 1 (insulin-dependent) diabetes, has been attributed to the hyperinsulinaemia resulting from insulin treatment [5].

Although studies in vitro indicate that insulin itself may cause insulin resistance at receptor as well as postreceptor sites [6-15], it is uncertain to what extent the hyperinsulinaemia observed in insulin resistant states in man may contribute to impaired insulin action or merely be a consequence of insulin resistance. Moreover, if hyperinsulinaemia does contribute to insulin resistance, it is unclear whether this occurs primarily at a receptor or post-receptor site.
Short-term infusions of insulin have been reported to decrease monocyte and erythrocyte insulin binding in normal human volunteers [16-19]. However, to date there is no direct evidence that insulin excess can cause insulin resistance. Studies in which rats were injected with insulin for 1-2 weeks [20-33] have yielded conflicting results, suggesting that either no insulin resistance resulted or insulin resistance occurred which was solely explicable by a decrease in insulin-receptor binding.

Because of the uncertainties regarding the role of hyperinsulinaemia in the pathogenesis of insulin resistance, the present study was undertaken to determine whether infusions of insulin can produce insulin resistance in man and, if so, whether this is due initially to a receptor or post-receptor defect.

\section{Materials and methods}

\section{Subjects}

Informed written consent was obtained from 13 normal volunteers after these studies were approved by the Mayo Clinic Human Studies Committee. All subjects were within $15 \%$ of their ideal body weight 
(Metropolitan Life Insurance Company Tables) and had no family history of diabetes mellitus. For $72 \mathrm{~h}$ before the study, subjects ate standard meals at the Clinical Research Center consisting of $45 \%$ carbohydrate, $35 \%$ fat and $20 \%$ protein $(30 \mathrm{kcal} / \mathrm{kg})$.

\section{Experimental design}

At $0700 \mathrm{~h}$ on the day of study the subjects, having fasted for $12-14 \mathrm{~h}$, were admitted to the Clinical Research Center. Monocyte and adipocyte insulin binding, as well as adipocyte glucose transport, oxidation and conversion to lipids were determined before and after a 6 -h infusion of insulin (eight women, one man, mean \pm SEM age $25 \pm 1$ years) or a $6-\mathrm{h}$ infusion of $7.7 \mathrm{mmol} / 1$ saline (three women, one man, mean age $35 \pm 5$ years). During this insulin infusion $\left(2 \mathrm{mU} \cdot \mathrm{kg}^{-1} \cdot \mathrm{min}^{-1}\right)$, plasma glucose was maintained at approximately $5.3 \mathrm{mmol} / \mathrm{l}$ using the glucose clamp technique described previously [16].

\section{Monocyte and adipocyte isolation}

Mononuclear cells were isolated from heparinized blood by a modification of the Ficoll-Hypaque technique [24]. Adipocytes were isolated by a modification [25] of the collagenase digestion method of Rodbell [26]. Approximately $6 \mathrm{~g}$ of subcutaneous adipose tissue were obtained from the left or right lower abdominal quadrant from the centre of an area anaesthetized locally in a square-field fashion [3]. The tissue was washed in warm $\left(37^{\circ} \mathrm{C}\right)$ saline $(0.15 \mathrm{mmol} / 1)$ and $1 \mathrm{~g}$ portions, which had been cut into $5 \times 5 \mathrm{~mm}$ pieces, were placed into polyethylene vessels. Each vessel contained $6 \mathrm{ml}$ Krebs-Ringer-bicarbonate buffer $(\mathrm{pH}$ 7.6 , at $37^{\circ} \mathrm{C}$ after gassing with $95 \% \mathrm{O}_{2}: 5 \% \mathrm{CO}_{2}$ ) containing $3.5 \%$ bovine plasma albumin (Armour Pharmaceuticals, Kankakee, Illinois, USA), glucose ( $5 \mathrm{mmol} / 1$ ), and collagenase ( $3 \mathrm{mg}$ ) (Worthington Biochemicals, Millipore Corporation, Freehold, New Jersey, USA). After shaking for $1 \mathrm{~h}$ at $37^{\circ} \mathrm{C}$, the digested tissue was passed first through a 1000 micron and then through a 250 micron nylon mesh. Care was taken to maintain the adipocytes at $37^{\circ} \mathrm{C}$ at all times. The cells were then centrifuged at $100 \mathrm{~g}$ in $16 \times 100 \mathrm{~mm}$ polyethylene tubes (A/S Nunc, Roskilde, Denmark), the infranatant was removed, and an equal volume of Krebs-Ringer bicarbonate buffer at $37^{\circ} \mathrm{C}$ was added. After resuspension by gentle inversion, the cells were recentrifuged and washed twice in the same manner into a Hepes buffer [(N-2-hydroxyethyl-piperazine- $\mathrm{N}^{\prime}$-2-ethane sulphonic acid) (10 mmol/1); $\mathrm{NaCl},(135 \mathrm{mmol} / \mathrm{l}) ; \mathrm{KCl}(4.8 \mathrm{mmol} / \mathrm{l}) ; \mathrm{CaCl}_{2} \cdot \mathrm{H}_{2} \mathrm{O}(2.5 \mathrm{mmol} / \mathrm{l}) ;$ $\mathrm{MgSO}_{4}(1.7 \mathrm{mmol} / 1) ; \mathrm{NaH}_{2} \mathrm{PO}_{4}(1.0 \mathrm{mmol} / 1) ; \mathrm{pH} 7.6$, at $37^{\circ} \mathrm{C}$ after gassing)] containing $5 \%$ bovine plasma albumin with bacitracin $(0.5 \mathrm{mg} / \mathrm{ml})$ (Sigma, St. Louis, Missouri) and either glucose $(5 \mathrm{mmol} / 1)$ (for determination of insulin binding) or no glucose (see below, for determination of $\left[{ }^{14} \mathrm{C}\right]-3-0$-methyl-D-glucose transport or incorporation of $\mathrm{U}-\left[{ }^{14} \mathrm{C}\right]-\mathrm{D}$-glucose into $\left[{ }^{14} \mathrm{C}\right]-\mathrm{CO}_{2}$ or $\left[{ }^{14} \mathrm{C}\right]-$ lipids). Following final resuspension of the cells, an aliquot was fixed in $1 \%$ osmium tetroxide in collidine- $\mathrm{HCl}$ buffer for cell counting and size analysis by a modification of the method of Hirsch and Gallian [27].

\section{Insulin binding}

$\left.{ }^{125} \mathrm{I}\right]$-insulin was prepared to a Sp. act. of $150-200 \mu \mathrm{Ci} / \mu \mathrm{g}$ from purified crystalline pork insulin (courtesy of Dr M. Root, Eli Lilly, Indianapolis, Indiana) as outlined by De Meyts [28], using stepwise addition of chloramine-T. Monocyte insulin binding was determined as previously described, using 1\% bovine serum albumin (Sigma) [18]. Adipocyte insulin binding was determined by a modification of the method of Pedersen and Hjollund [5]. Isolated adipocytes (approximately $5 \times 10^{5} / \mathrm{ml}$ ) were incubated in triplicate in a final volume of $0.5 \mathrm{ml}$ Hepes buffer, containing $0.825 \mathrm{U} / 1\left[{ }^{125} \mathrm{I}\right.$ ]-insulin and 0,5 or $625 \mathrm{mU} / 1$ unlabelled insulin. Non-specific binding was defined as $\left[{ }^{125} \mathrm{I}\right]$-insulin bound in the presence of $250000 \mathrm{mU} / \mathrm{l}$ unlabelled insulin and was subtracted from all other values. Incubations were carried out with slow shaking at $37^{\circ} \mathrm{C}$ for $1 \mathrm{~h}$. Following incubation, duplicate $0.2 \mathrm{ml}$ aliquots were removed from each tube and centrifuged at $10000 \mathrm{~g}$ for $90 \mathrm{~s}$ through $0.2 \mathrm{ml}$ silicone oil (Silwet 722, Union Car- bide, Danbury, Connecticut) in a Beckman microcentrifuge (Palo Alto, California, USA). The portion of the centrifuge tube containing the cells, which float on the oil, was excised and its radioactivity was counted using a gamma counter (Searle, Des Plaines, Illinois, USA). Results were expressed as insulin bound specifically $/ 2 \times 10^{5}$ adipocytes. Incubations carried out in this manner result in steady-state binding at $30-45 \mathrm{~min}$ which is maintained for at least $150 \mathrm{~min}$.

\section{$\left[{ }^{14} C\right]-3-0-m e t h y l-D$-glucose transport}

Adipocyte glucose transport was assessed using $\left[{ }^{14} \mathrm{C}\right]-3-0$-methyl-D glucose, a non-metabolizable glucose derivative $[29,30]$. Transport of this analogue was determined following exposure in duplicate of isolated adipocytes (approximately $10^{6} / \mathrm{ml}$ ) to 0,5 or $625 \mathrm{mU} / 1$ insulin in $16 \times 100 \mathrm{~mm}$ polyethylene tubes in a final volume of $0.4 \mathrm{ml}$ Hepes buffer (without glucose) at $37^{\circ} \mathrm{C}$ with slow shaking for $1 \mathrm{~h}$. Following exposure to insulin, triplicate $50 \mu \mathrm{l}$ aliquots of cells were pipetted directly into $20 \mu \mathrm{l}$ of $0.15 \mathrm{~mol} / 1 \mathrm{NaCl}$ containing $0.4 \mu \mathrm{Ci}\left[{ }^{14} \mathrm{C}\right]-3-0-$ methyl-D-glucose (New England Nuclear Corporation, Cambridge, Massachusetts) and $0.4 \mu \mathrm{Ci}\left[{ }^{3} \mathrm{H}\right]$-L-glucose (New England Nuclear) as a marker for non-specific cell-associated radioactivity. The final concentration of 3-0-methyl-D-glucose was $17.4 \mu \mathrm{mol} / 1$. Reactions were terminated after $15 \mathrm{~s}$ by the rapid addition with a syringe pipettor of $8 \mathrm{ml}$ cold $0.3 \mathrm{mmol} / 1$ phloretin (Sigma) in $0.15 \mathrm{~mol} / 1 \mathrm{NaCl}$ to block further glucose transport. Approximately $2 \mathrm{ml}$ silicone oil was layered onto the phloretin cell mixture, and the tubes were centrifuged at $1500 \mathrm{~g}$ for $30 \mathrm{~s}$. The adipocytes, which float on top of the oil, were collected and placed in scintillation fluid (Safety Solve Research Products International, Mount Prospect, Illinois) for dual counting of tritium and carbon-14. Results corrected for non-specific cell associated radioactivity were expressed as pmol 3-0-methyl-D-glucose transported per $2 \times 10^{5}$ adipocytes in $15 \mathrm{~s}$. Using this technique, transport rates were found to be linear for approximately $20 \mathrm{~s}$ following exposure to 3-0-methyl-D-glucose.

\section{Glucose oxidation}

Production of $\left[{ }^{14} \mathrm{C}\right]-\mathrm{CO}_{2}$ from $\mathrm{U}-\left[{ }^{14} \mathrm{C}\right]-\mathrm{D}$-glucose (New England $\mathrm{Nu}-$ clear) was determined by incubating isolated adipocytes (approximately $5 \times 10^{5}$ cells $/ \mathrm{ml}$ ) in duplicate in $16 \times 100 \mathrm{~mm}$ polyethylene tubes in a volume of $0.5 \mathrm{ml}$ Hepes buffer (without unlabelled glucose) containing 0.033 or $4.25 \mathrm{nmol} / 1$ insulin and labelled glucose $(1 \mu \mathrm{Ci}$, final concentration $5.6 \mu \mathrm{mol} / \mathrm{l}$ ) at $37^{\circ} \mathrm{C}$ with slow shaking for $90 \mathrm{~min}$. After the addition of adipocytes, tubes were sealed with rubber stoppers through which plastic centre wells were suspended. After incubation, $0.2 \mathrm{ml} \mathrm{H}_{2} \mathrm{SO}_{4}(0.5 \mathrm{~mol} / 1)$ was injected through the stopper into the cell suspension to liberate $\left[{ }^{14} \mathrm{C}\right]-\mathrm{CO}_{2}$, and $0.2 \mathrm{ml} 1 \mathrm{~N}$ hyamine hydroxide was injected through the stopper into the centre well for collection of $\left[{ }^{14} \mathrm{C}\right]-\mathrm{CO}_{2}$. After radioactivity was collected overnight, the centre wells were removed and placed in scintillation fluid for counting. Results were expressed as pmol glucose converted to $\mathrm{CO}_{2} / 2 \times 10^{5}$ cells in $90 \mathrm{~min}$. [ ${ }^{14} \mathrm{C}-\mathrm{CO}_{2}$ produced by tissue blanks was less than $1 \%$ of values in the presence of adipocytes.

\section{Incorporation of glucose into lipids}

Incorporation of U-[ $\left[{ }^{14} \mathrm{C}\right]-\mathrm{D}$-glucose into total adipocyte lipids was determined by incubating isolated adipocytes (approximately $5 \times 10^{5}$ cells $/ \mathrm{ml}$ ) in duplicate in $16 \times 100 \mathrm{~mm}$ polyethylene tubes in a volume of $0.5 \mathrm{ml}$ Hepes buffer (without unlabelled glucose) containing $0,0.033$ or $4.25 \mathrm{nmol} / 1$ insulin and labelled glucose $(1 \mu \mathrm{Ci})$ at $37^{\circ} \mathrm{C}$ with slow shaking for $90 \mathrm{~min}$. After the incubation, total lipids in $0.4 \mathrm{ml}$ aliquots of cell suspension from each tube were extracted in chloroform-methanol [31]. The resulting organic phase was dried with air and redissolved in scintillation fluid for counting. $\left[{ }^{3} \mathrm{H}\right]$-triolein $(0.1 \mu \mathrm{Ci}$, New England Nuclear) was added to each extraction tube to determine extraction recoveries. These recoveries ranged from 75 to $95 \%$, and all data were corrected accordingly. 
Table 1. Glucose infusion rates necessary to maintain euglycaemia during 6-h insulin infusions

\begin{tabular}{lrrrrrrr}
\hline & \multicolumn{2}{l}{ Time (h) } & & & & \\
\cline { 2 - 7 } & 1 & 2 & 3 & 4 & 5 & \multicolumn{1}{c}{6} \\
\hline Glucose & 6.07 & 6.72 & 7.6 & 8.66 & 9.28 & 9.47 \\
infusion rates & \pm 0.99 & \pm 0.86 & \pm 0.67 & \pm 0.66 & \pm 0.64 & \pm 0.68 \\
$\left(\mathrm{mg} \cdot \mathrm{kg}^{-1}\right.$. & & & & & & \\
$\left.\min ^{-1}\right)$ & & & & & & \\
\hline
\end{tabular}

Results expressed as mean \pm SEM for nine experiments

Table 2. Effect of hyperinsulinaemia on monocyte and adipocyte insulin binding

\begin{tabular}{|c|c|c|}
\hline & \multicolumn{2}{|c|}{ Insulin binding } \\
\hline & $(5 \mathrm{mU} / 1)^{\mathrm{a}}$ & $(625 \mathrm{mU} / 1)^{\mathrm{a}}$ \\
\hline \multicolumn{3}{|c|}{ Monocytes (\% per $10^{7}$ cells) } \\
\hline \multicolumn{3}{|c|}{ Saline infusion $(n=4)$} \\
\hline Before & $8.9 \pm 0.6$ & $1.4 \pm 0.1$ \\
\hline After & $9.0 \pm 1.1$ & $1.6 \pm 0.3$ \\
\hline \multicolumn{3}{|c|}{ Insulin infusion $(n=9)$} \\
\hline Before & $7.2 \pm 0.6$ & $1.3 \pm 0.1$ \\
\hline After & $6.2 \pm 0.6^{\mathrm{b}}$ & $1.1 \pm 0.1^{b}$ \\
\hline \multicolumn{3}{|c|}{ Adipocytes $\left(\%\right.$ per $2 \times 10^{5}$ cells $)$} \\
\hline \multicolumn{3}{|c|}{ Saline infusion $(n=4)$} \\
\hline Before & $4.0 \pm 0.8$ & $0.7 \pm 0.1$ \\
\hline After & $3.8 \pm 0.8$ & $0.7 \pm 0.2$ \\
\hline \multicolumn{3}{|c|}{ Insulin infusion $(n=9)$} \\
\hline Before & $4.6 \pm 0.5$ & $0.8 \pm 0.1$ \\
\hline After & $4.4 \pm 0.4$ & $0.8 \pm 0.1$ \\
\hline
\end{tabular}

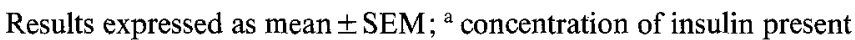
in binding assay; ${ }^{\mathrm{b}} p<0.05$, significant change from before insulin infusion

\section{Plasma glucose and insulin determinations}

Plasma glucose and insulin determinations were made on arterializedvenous specimens using a glucose analyzer (Yellow Springs Instruments, Yellow Springs, Ohio) and a dextran-coated charcoal technique [32], respectively.

\section{Statistical analyses}

Data are given as mean \pm SEM. Statistical evaluation was performed using two-way analysis of variance for repeated measures and posteriori t-tests [33]. A $p$ value $<0.05$ was considered significant.

\section{Results}

\section{Plasma glucose and insulin concentrations}

Baseline plasma glucose and insulin concentrations prior to infusions of insulin and saline were comparable $(5.3 \pm 0.1$ versus $5.2 \pm 0.1 \mathrm{mmol} / 1$ and $10 \pm 1$ versus $11 \pm 1 \mathrm{mU} / 1)$. During infusion of insulin, plasma insulin increased to a stable concentration of $140 \pm 13 \mathrm{mU} / 1$, and plasma glucose was maintained at $5.3 \pm 0.1 \mathrm{mmol} / 1$ (coefficient of variation $5 \%$ ). During infusion of saline, plasma glucose and plasma insulin averaged $5.3 \pm$

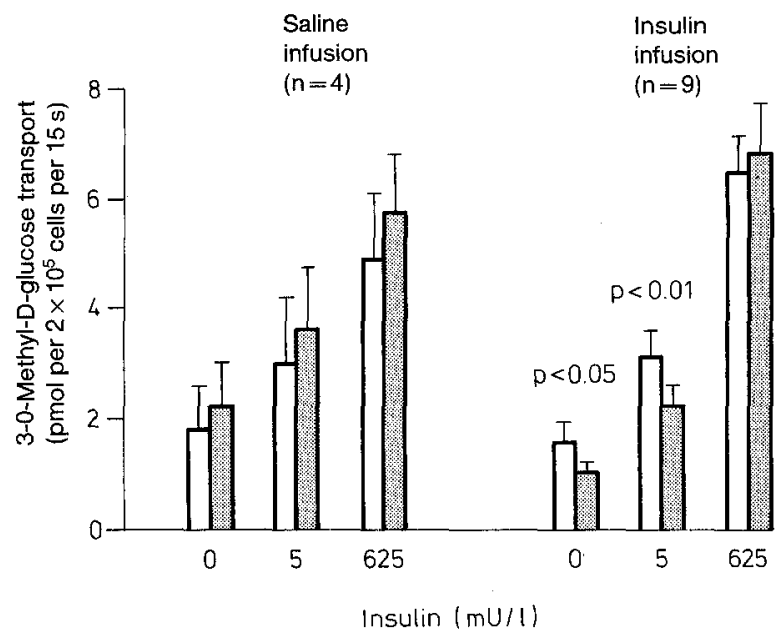

Fig. 1. Effect of infusion of insulin or saline in normal volunteers on adipocyte glucose transport in vitro. $\square$ : before infusion; : : after infusion (mean \pm SEM)

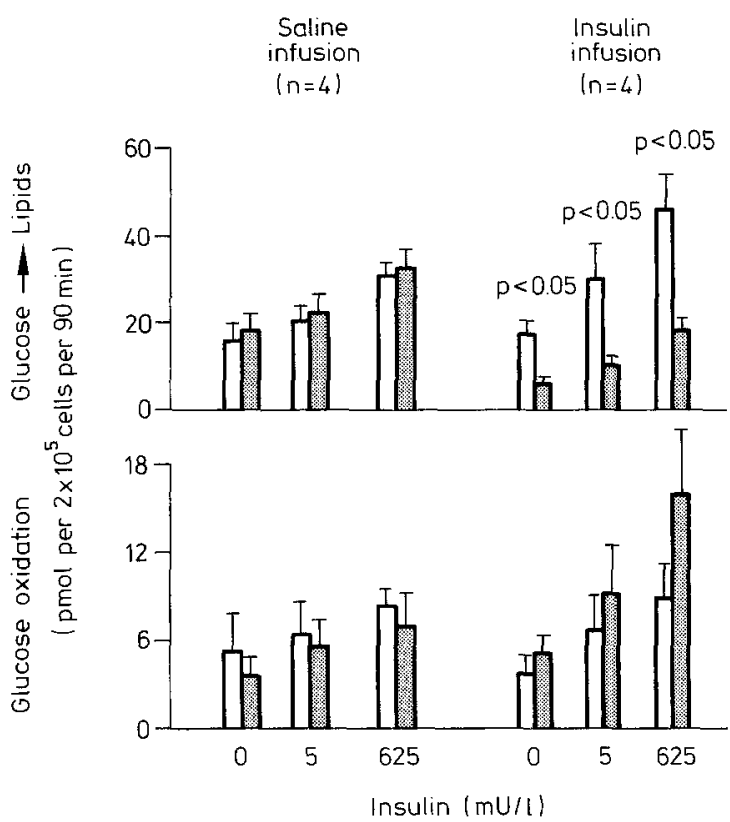

Fig. 2. Effect of infusion of insulin or saline in normal volunteers on adipocyte lipogenesis and glucose oxidation in vitro. $\square$ : before infusion; : : after infusion (mean \pm SEM)

$0.1 \mathrm{mmol} / 1$ and $8 \pm 1 \mathrm{mU} / 1$, respectively. Glucose infusion rates necessary to maintain euglycaemia are given at hourly intervals in Table 1 . Glucose infusion rates increased progessively until reaching near-steadystate between 4 and $5 \mathrm{~h}$. Values at $4 \mathrm{~h}$ were not significantly different from those at the end of the 6-h infusion.

\section{Monocyte and adipocyte insulin binding}

Monocyte insulin binding decreased 15\% after infusion of insulin and did not change after infusion of saline $(p<0.05)$. In contrast, neither infusion of insulin nor infusion of saline altered adipocyte insulin binding or di- 
ameter (mean \pm SEM: $91 \pm 2$ versus $90 \pm 3 \mu \mathrm{m}$ before and after insulin; $87 \pm 11$ versus $90 \pm 11 \mu \mathrm{m}$ before and after saline; Table 1).

\section{Adipocyte glucose transport}

After infusion of insulin, glucose transport in the absence of insulin and at a submaximally effective insulin concentration $(5 \mathrm{mU} / \mathrm{l})$ were both decreased approximately $30 \%(p<0.05$ and 0.01 , respectively), whereas glucose transport at a maximally effective insulin concentration $(625 \mathrm{mU} / 1)$ was unaffected (Fig.1). Since basal ( $0 \mathrm{mU} / 1$ insulin) glucose transport rates were decreased following infusion of insulin, glucose transport data were expressed in terms of increment above basal per pmol insulin bound. When these data were analyzed, the increment in glucose transport at the submaximally effective insulin concentration $(5 \mathrm{mU} / 1)$ was still significantly decreased following hyperinsulinaemia ( $720 \pm 120$ versus $1140 \pm 180 \mathrm{pmol} / \mathrm{pmol}$ insulin bound, $p<0.05)$. After infusion of saline, glucose transport in the presence or absence of insulin was not decreased.

\section{Adipocyte glucose conversion to lipids and glucose oxidation}

Conversion of glucose to lipids was decreased more than $50 \%$ after infusion of insulin in the absence of insulin and at both submaximally and maximally effective insulin concentrations ( $p<0.05$; Fig. 2 ); no change was observed after infusion of saline. In contrast, both basal and insulin-stimulated adipocyte glucose oxidation were unaltered after infusion of insulin or saline.

\section{Discussion}

In the present study, hyperinsulinaemia decreased monocyte insulin binding but did not alter adipocyte insulin binding. Furthermore, the hyperinsulinaemia decreased adipocyte glucose transport and conversion of glucose to lipids but did not affect glucose oxidation. These results indicate that hyperinsulinaemia may cause insulin resistance and that, at least initially, this insulin resistance is due to cellular abnormalities not involving the insulin receptor, i.e., a so-called post-receptor defect. It is possible that more prolonged hyperinsulinaemia may have resulted in decreased adipocyte insulin binding, since other workers found that prolonged experimentally-induced hyperinsulinaemia decreased adipocyte insulin binding in rats $[22,23]$.

The present study confirms that short-term hyperinsulinaemia can decrease monocyte insulin binding [16-18]. Similar insulin-induced decreases in erythrocyte insulin binding have been reported in some $[18,19]$ but not all studies [16]. However, in the present study, adipocyte insulin binding was not affected by shortterm hyperinsulinaemia. Pedersen and Hjollund [5] also found a dissociation between monocyte and adipocyte insulin binding. Taken together, these observations suggest that monocyte insulin binding, which is commonly thought to reflect insulin binding in insulin-sensitive tissues, may not always do so.

Theoretically it is possible that a small decrease in adipocyte insulin binding may not have been detected in the present study. However, it is unlikely for several reasons, that such a decrease, if present, could account for the observed impairment in glucose metabolism. A decrease in insulin binding alone would have been expected to result in a decrease in intracellular glucose metabolism which was proportional to an accompanying decrease in glucose transport. However, in the present study, insulin stimulated glucose oxidation was not decreased whereas glucose transport was. Moreover, in the absence of added insulin both glucose transport and conversion to lipids were decreased, further suggesting that short-term hyperinsulinaemia had produced a cellular defect. It should be pointed out though, that some of the decrease in glucose conversion into lipids may have been due to anti-lipolysis induced by the insulin infusion. This could have decreased the availability of intracellular glucose-derived glycerol into lipids.

The finding of a metabolic defect induced by insulin in vivo, which could not be accounted for by a decrease in insulin binding, is in accord with studies in vitro demonstrating that exposure of rat adipocytes and myoblasts to increased insulin concentrations can produce post-receptor defects in glucose metabolism [12, 15]. Conventionally, an abnormality in insulin action is referred to as a receptor defect if there is decreased insulin receptor binding and is considered a post-receptor defect if subsequent events are involved. Such events may include physico-chemical alteration of the receptor, generation of an intracellular mediator and responses of cellular enzymes or organelles to the mediator. The fact that both basal and insulin-stimulated glucose transport were decreased following infusion of insulin suggest that certain cellular processes distal to insulin receptor binding (e.g. availability of glucose transporters) may have been adversely affected by the antecedent hyperinsulinaemia in such a way as to render them less responsive to insulin, i.e. a post-receptor defect.

Our findings have implications concerning the pathological sequence of events leading to the association of hyperinsulinaemia and decreased insulin binding in obesity. It is currently thought that in obesity [1-4], hyperinsulinaemia due to over-eating may initially cause insulin resistance by down-regulating insulin receptors and that, as insulin resistance progresses, a post-receptor defect may emerge. Our results suggest that hyperinsulinaemia may first cause a post-receptor defect. A non-rate-limiting post-receptor defect in insulin action would result in only a shift to the right of an insulin dose-reponse curve [37-42]. Thus, if subsequent down-regulation of insulin receptors were to occur, a modest post-receptor defect might not be detected even 
when the biological responses to insulin were related to insulin receptor occupancies. This might explain the apparent presence of only a receptor defect in many hyperinsulinaemic patients with obesity and Type 2 diabetes [1-4]. Similarly the decreased insulin receptor binding found in some hyperinsulinaemic patients with Type 1 [5] or Type 2 diabetes [1, 37, 43], in association with a post-receptor defect, could be a later event which has been preceded by a post-receptor defect. Such a postulate is supported by the observation that post-receptor defects may occur in diabetic patients in the apparent absence of decreased adipocyte insulin binding [37]. Moreover, down-regulation of insulin binding by insulin is considered to be dependent upon post-receptor actions of insulin $[6,44-46]$.

It should be pointed out that in the present studies glucose was infused along with insulin to maintain euglycaemia. However, according to current knowledge [47] only trivial amounts of the glucose infused in the present studies would have been taken up by adipose tissue. In any study of induced hyperinsulinaemia in man, such an infusion of glucose is a necessary but potentially confounding variable, since increased glucose uptake itself may influence the outcome of such experiments. However, the increased glucose uptake is a direct effect of hyperinsulinaemia so it is not clear whether the mechanisms for changes induced by these intimately linked events can, or should, be differentiated.

Finally, our finding that hyperinsulinaemia may cause insulin resistance provides an explanation why insulin therapy may not always improve $[48,49]$ or completely normalize [50] insulin resistance in Type 2 diabetes. Although insulin therapy may correct defects in insulin action due to insulin deficiency [50], if it results in hyperinsulinaemia, it may conceivably itself produce insulin resistance.

In summary, the present studies indicate that hyperinsulinaemia can cause insulin resistance in man and that, at least initially, this is due to a post-receptor defect. Thus decreased insulin receptor binding, when accompanied by hyperinsulinaemia and a post-receptor defect, may be a secondary event.

Acknowledgements. We thank J.Kahl, J. King, T.Lund, R. Westland, W. Blanchard, K. Kluge, and the staff of the Clinical Study Unit for their excellent technical assistance, and P. Voelker for her editorial help. Funded in part by grants from the United States Public Health Service (AM-20411, AM-07352, RR00585, AM-29953), the American Diabetes Association and the Mayo Foundation. Dr. Mandarino is the recipient of the Rosalyn Yalow Research and Development Award from the American Diabetes Association.

\section{References}

1. Olefsky J, Kolterman O, Scarlett J (1982) Insulin action and resistance in obesity and noninsulin-dependent type II diabetes mellitus. Am J Physiol 243: E15-E30

2. Bar R, Gorden P, Roth J, Kahn C, DeMeyts P (1976) Fluctuations in the affinity and concentrations of insulin receptors on circulating monocytes of obese patients. J Clin Invest 58:1123-1135

3. Kolterman O, Insel J, Saekow M, Olefsky J (1980) Mechanisms of insulin resistance in human obesity. J Clin Invest 65:1272-1284

4. Taylor A, Blackard W (1982) Role of insulin receptors in obesityrelated diabetes. Horm Metab Res 14: 623-626

5. Pedersen O, Hjollund E (1982) Insulin receptor binding to fat and blood cells and insulin action in fat cells from insulin-dependent diabetics. Diabetes 31: 706-715

6. Gavin J, Roth J, Neville D, DeMeyts P, Buell D (1974) Insulin dependent regulation of insulin receptor concentrations. A direct demonstration in cell culture. Proc Natl Acad Sci USA 71: 84-88

7. Mott D, Howard B, Bennett P (1979) Stoichiometric binding and regulation of insulin receptors on human diploid fibroblasts using physiologic insulin levels. J Biol Chem 254: 8762-8767

8. Baldwin D, Prince M, Marshall S, Davies P, Olefsky J (1980) Regulation of insulin receptors: evidence for involvement of an endocytotic-internalization pathway. Proc Natl Acad Sci 77: 5975-5978

9. Blackard W, Guzelian P, Small M (1978) Downregulation of insulin receptors in primary cultures of adult rat hepatocytes in monolayer. Endocrinology 103: 548-553

10. Caro J, Amatrude J (1980) Insulin receptors in hepatocytes: postreceptor events mediate downregulation. Science 210: 1029-1031

11. Huang D, Cuatrecasas $P(1975)$ Insulin-induced reduction of membrane receptor concentrations in isolated fat cells and lymphocytes. J Biol Chem 250: 8251-8259

12. Marshall S, Olefsky J (1980) Effects of insulin incubation on insulin binding, glucose transport, and insulin degradation by isolated rat adipocytes. $\mathrm{J}$ Clin Invest 66: 763-771

13. Livingston J, Purvis B, Lockwood D (1978) Insulin-induced changes in insulin binding and insulin sensitivity of adipocytes. Metabolism 27: 2009-2014

14. Amatruda J, Newmeyer H, Chang C (1982) Insulin-induced alterations in insulin binding and insulin action in primary cultures of rat hepatocytes. Diabetes 31: 145-148

15. Davidson M, Casanello-Ertl D (1979) Insulin antagonism in cultured rat myoblasts secondary to chronic exposure to insulin. Horm Metab Res 11: 187-260

16. Rizza R, Mandarino L, Gerich J (1981) Dose response characteristics for effects of insulin on production and utilization of glucose in man. Am J Physiol 240: E630-E639

17. Baker B, Mandarino L, Brick B, Rizza R, Gerich J (1984) Influence of changes in insulin receptor binding during insulin infusions on the shape of the insulin dose-response curve for glucose disposal in man. J Clin Endocrinol Metab 58: 392-396

18. Insel J, Kolterman O, Sackow M, Olefsky J (1980) Short-term regulation of insulin receptor affinity in man. Diabetes 29: 132-139

19. Doberne L, Greenfield M, Schulz B, Reaven G (1981) Enchanced glucose utilization during prolonged glucose clamp studies. Diabetes 30: 829-835

20. Kobayashi M, Olefsky J (1979) Effect of experimental hyperinsulinaemia on intracellular glucose metabolism of isolated adipocytes. Diabetologia 17: 111-116

21. Kobayashi M, Olefsky J (1978) Long-term regulation of adipocyte glucose transport capacity by circulating insulin in rats. J Clin Invest 62: 73-81

22. Kobayashi M, Olefsky J (1978) Effect of experimental hyperinsulinemia on insulin binding and glucose transport in isolated rat adipocytes. Am J Physiol 4: E53-E62

23. Whittaker J, Alberti K (1979) The effects of chronic hyperinsulinemia on insulin binding and glucose metabolism in rat adipocytes. Biochem Soc Trans 7: 1055-1056

24. Boyum A (1968) A one-stage procedure for isolation of granulocytes and lymphocytes from human blood. Scand J Clin Lab Invest 21 [Suppl 97]: 51-76

25. Pedersen O, Hjollund E, Beck-Nielsen H, Lindskov $H$, Sonne O, Gliemann J (1981) Insulin receptor binding and receptor-mediated insulin degradation in human adipocytes. Diabetologia 20: 636-641

26. Rodbell M (1964) Metabolism of isolated fat cells. I. Effects of 
hormones on glucose metabolism and lipolysis. J Biol Chem 239: 375-380

27. Hirsch J, Gallian E (1968) Methods for the determination of adipose cell size in man and animals. J Lipid Res 9:110-119

28. De Meyts P (1976) Insulin and growth hormone receptors in human cultured lymphocytes and peripheral blood monocytes. In: Blecher M (ed) Methods of receptor research. Dekker, New York, pp 301-383

29. Whitesell R, Gliemann $\mathbf{J}$ (1979) Kinetic parameters of transport of 3-0-methyl glucose and glucose in adipocytes. J Biol Chem 254: $5276-5283$

30. Ciaraldi T, Kolterman O, Siegal J, Olefsky J (1979) Insulin-stimulated glucose transport in human adipocytes. Am J Physiol 236: E621-E625

31. Bligh E, Dyer W (1959) A rapid method of total lipid extraction. Can J Biochem Physiol 37: 911-917

32. Herbert V, Lau K, Gottlieb C, Bleicher S (1965) Coated charcoal immunoassay of insulin. J Clin Endocrinol Metab 25: 1375-1384

33. Winer B (1971) Statistical principles in experimental design. McGraw-Hill, New York

34. Savage P, Bennion L, Flock E, Nagulesparan M, Mott D, Roth J, Unger R, Bennett PL (1979) Diet-induced improvement of abnormalities in insulin and glucagon secretion and in insulin receptor binding in diabetes mellitus. J Clin Endocrinol Metab 48: 999-1007

35. Archer J, Gorden P, Roth J (1975) Defect in insulin binding to receptors in obese man. J Clin Invest 55: 166-174

36. Kahn C, Flier J, Bar R, Archer J, Gorden P, Martin M, Roth J (1976) The syndromes of insulin resistance and acanthosis nigricans. N Engl J Med 294: 739-745

37. Kolterman O, Gray R, Griffin J, Bernstein P, Insel J, Scarlett J, Olefsky J (1981) Receptor and postreceptor defects contribute to the insulin resistance in non-insulin-dependent diabetes mellitus. $\mathrm{J}$ Clin Invest 68:957-969

38. Olefsky J (1975) Effect of dexamethasone on insulin binding, glucose transport and glucose oxidation of isolated rat adipocytes. $\mathbf{J}$ Clin Invest 56: 1499-1508

39. Czech M, Fain J (1972) Antagonism of insulin action on glucose metabolism in white fat cells by dexamethasone. Endocrinology 91: $518-522$

40. Haring H, Rinninger R, Kemmler W (1981) Decreased insulin sensitivity due to a postreceptor defect as a consequence of ATP-deficiency in fat cells. FEBS Lett 132: 235-238
41. Rizza R, Mandarino L, Gerich J (1982) Cortisol-induced insulin resistance in man: impaired suppression of glucose production and stimulation of glucose utilization due to a post-receptor defect of insulin action. J Clin Endocrinol Metab 54: 131-138

42. Rizza R, Mandarino L, Gerich J (1982) Effects of growth hormone on insulin action in man. Mechanisms of insulin resistance, impaired suppression of glucose production, and impaired stimulation of glucose utilization. Diabetes 31: 663-669

43. Beck-Nielsen $H$ (1978) The pathogenic role of an insulin receptor defect in diabetes mellitus of obese. Diabetes 27:1175-1181

44. Filetti S, Takai N, Rapaport B (1981) Insulin receptor down-regulation prevention at a postreceptor site. Endocrinology 108: 2409-2411

45. Lane M (1981) The regulation of insulin receptor level and activity. Nutr Rev 39: 417-425

46. Gorden P, Carpentier J, Fang J, Orci L (1982) Receptor mediated endocytosis of polypeptide hormones: mechanism and significance. Metabolism 31: 664-669

47. Bjorntorp P, Sjostrom L (1978) Carbohydrate storage in man: speculations and some quantitative considerations. Metabolism 27 (Suppl 2): 1853-1865

48. Ginsberg H, Rayfield R (1981) Effect of insulin therapy on insulin resistance in type II diabetic subjects. Evidence for heterogeneity. Diabetes 30: 739-745

49. Hidaka H, Nagulesparan M, Klives I, Clark R, Sasaki H, Aronoff S, Vasquez B, Rubenstein A, Unger R (1982) Improvement of insulin secretion but not insulin resistance after short-term control of plasma glucose in obese type II diabetics. J Clin Endocrinol Metab 54: 217-222

50. Scarlett J, Gray R, Griffin J, Olefsky J, Kolterman O (1982) Insulin treatment reverses the insulin resistance of type II diabetes mellitus. Diabetes Care 5: 353-363

Received: 14 July 1983

and in revised form: 12 June 1984

John E. Gerich

Endocrine Research Unit

Mayo Clinic

Rochester.

Minnesota 55905

USA 